Web Jurnal:

http://ejournal.kemenperin.go.id/jli

\title{
Pengaruh penambahan limbah tongkol jagung untuk pembuatan batu bata ringan
}

\section{The adding effect of corncob waste for making of light bricks}

\author{
Ardinal ${ }^{* 1}$, Rahma Wirni ${ }^{2}$, Nur Aini Haryati ${ }^{1}$ \\ 1 Balai Riset dan Standardisasi Industri Padang \\ Jl. Raya LIK No. 23 Ulu Gadut, Padang, Indonesia \\ 2 CV. Lentera, Siteba, Padang, Indonesia \\ * e-mail: ardinal_ok@yahoo.co.id
}

\begin{tabular}{l}
\hline INFO ARTIKEL \\
\hline Sejarah artikel: \\
Diterima: \\
11 Mei 2020 \\
Direvisi: \\
18 Juni 2020 \\
Diterbitkan: \\
29 Juni 2020 \\
\hline
\end{tabular}

\section{Kata kunci:}

bata komposit; tongkol jagung; batu bata

\begin{abstract}
ABSTRAK
Pemakaian tanah lempung sebagai bahan baku batu bata dapat dikurangi dengan menambahkan serat. Salah satu sumber serat yang pemanfaatannya belum optimal yaitu limbah tongkol jagung. Untuk itu, telah dilakukan penelitian dengan memanfaatkan tongkol jagung untuk substitusi pembuatan batu bata dengan mengacu kepada SNI 152094-2000. Perlakuan pembuatan batu bata komposit menggunakan bahan substitusi tongkol jagung yang dihaluskan hingga mencapai ukuran butir lolos ayakan $>60$ mesh dan $<60$ mesh dengan masing-masing penambahan tongkol jagung $0 \%, 2,5 \%, 5,0 \%$, $7,5 \%, 10 \%$ dan $12,5 \%$. Hasil penelitian menunjukan bahwa kualitas batu bata dengan ukuran butir tongkol jagung $>60$ mesh dengan perlakuan substitusi tongkol jagung hingga 12,5\% masih memenuhi kuat tekan kelas 50 menurut SNI 15-2094-2000, sedangkan untuk ukuran butir $<60$ mesh hanya substitusi tongkol jagung sampai 7,5\% yang memenuhi kelas 50 menurut SNI 15-2094-2000. Uji daya serap air menunjukkan bahwa semakin besar penambahan tongkol jagung, baik dengan ukuran butiran $>60$ mesh maupun $<60$ mesh, daya serap air semakin naik. Daya serap air rata-rata yang diperoleh lebih dari $20 \%$ sehingga belum memenuhi persyaratan daya serap air maksimum yang ditetapkan oleh SNI 15-2094-2000 yaitu sebesar 20\%. Dari hasil pemanfaatan tongkol jagung untuk substitusi pembuatan batu bata, perlakuan ukuran butir lolos $>60$ mesh dengan penambahan sampai $12,5 \%$ dapat digunakan karena telah memenuhi syarat kuat tekan SNI 15-2094-2000 kelas 50.
\end{abstract}

\begin{abstract}
The use of clay as raw material for bricks can be reduced by adding fiber. One source of fiber that has not been used optimally is corncob waste. For this reason, a study has been carried out by utilizing corncobs for substitution material in the manufacture of bricks with reference to SNI 15-2094-2000. The treatment of making composite bricks using corncob substitution material which was mashed to reach the grain size escaped sieve $>60$ mesh and $<60$ mesh with each addition of corncobs $0 \%, 2.5 \%, 5.0 \%, 7.5 \%, 10 \%$ and $12.5 \%$. The results showed that the quality of bricks with grain size $>60$ mesh with substitution of corncobs up to $12.5 \%$ remain met the compressive strength of class 50 according to SNI 15-2094-2000, while for grain size <60 mesh only substitution of corn cobs up to 7.5\% that meet class 50 according to SNI 15-2094-2000. Water absorption test showed that the bigger the addition of corncobs, the bigger the water absorption, both with grain size $>60$ mesh and $<60$ mesh. The average water absorption was more than $20 \%$ and did not meet the maximum water absorption requirements according to SNI 15-2094-2000 which is 20\%. From the results of the utilization of corn cobs for brick making substitution, the treatment of escaped grain size $>60$ mesh with the addition of up to $12.5 \%$ can be used because it meets the compressive strength requirements of SNI 15 2094-2000 class 50.
\end{abstract}




\section{Pendahuluan}

Batu bata adalah bahan bangunan yang telah lama dikenal dan dipakai oleh masyarakat baik di pedesaan maupun di perkotaan, mulai dari negara berkembang hingga negara maju. Batu bata berfungsi sebagai bahan bangunan konstruksi yang termasuk kedalam bahan utama. Pemanfaatan batu bata sebagai bahan utama suatu bangunan selain memberikan ketahanan terhadap suatu bangunan juga diharapkan untuk mendapatkan nilai artistik dari suatu bangunan tersebut.

Pemanfaatan batu bata sebagai bahan baku utama konstruksi baik sebagai pembentuk elemen struktural maupun non struktural sampai saat ini belum banyak digantikan. Hal ini dapat terlihat dengan masih banyaknya proyek konstruksi yang memanfaatkan batu bata sebagai dinding pada pembangunan gedung, perumahan, pagar, saluran, dan pondasi. Tingginya tingkat kebutuhan akan batu bata memberi peluang kepada masyarakat untuk terus memproduksi batu bata (Fattah and Nabi, 2018). Meningkatnya kebutuhan akan batu bata ini dapat dilihat dari banyaknya bedeng batu bata yang dibangun masyarakat. Penambahan bedeng ini bertujuan meningkatkan kapasitas produksi batu bata sehingga dapat memenuhi permintaan konsumen. Namun pembuatan batu bata saat ini masih menggunakan tanah lempung sebagai bahan baku. Tanah lempung ini didapatkan dengan mengeksploitasi sumberdaya alam. Eksploitasi tanah lempung akibat pembuatan batu bata merupakan salah satu penyebab terjadinya kerusakan struktur tanah. Kerusakan tanah dapat diidentifikasi dengan adanya lubang yang terdapat pada lahan bekas penambangan (Firmansyah et al., 2008).

Kawasan industri batu bata di Nagari Aripan, Kecamatan X Koto Singkarak, Kabupaten Solok telah meninggalkan lubang-lubang galian sedalam 2-8 m. Di daerah ini terdapat kurang lebih 900 bedeng batu bata dimana kurang lebih 500 bedeng diantaranya masih beroperasi. Bedeng-bedeng tersebut memiliki kapasitas pembakaran 10.000-60.000 batu bata. Satu kali produksi membutuhkan waktu empat bulan sehingga diketahui rata-rata kebutuhan tanah lempung (clay) untuk pembuatan batu bata sebesar $\pm 26.090 \mathrm{~m}^{3} /$ tahun. Untuk mendapatkan bahan baku tersebut, petani batu bata melakukan penggalian tanah lempung yang digunakan sebagai bahan baku. Berdasarkan Keputusan Menteri Lingkungan Hidup Nomor 43 Tahun 1996 tentang Kriteria Kerusakan Lingkungan Bagi Usaha atau Kegiatan Penambangan Bahan Galian Golongan C Jenis Lepas di Daratan lampiran I, dinyatakan bahwa dengan kedalaman lubang yang lebih dari satu meter dari permukaan air tanah pada musim hujan maka dikategorikan rusak. Sedangkan pada lampiran II menyatakan bahwa kedalaman lubang galian yang dimaksud adalah jarak vertikal dari permukaan lahan hingga ke dasar lubang galian (Kepmen Lingkungan Hidup, 1996).

Handayani (2010) menyatakan bahwa penambahan serat kayu untuk pembuatan batu bata komposit tidak mengurangi kualitas dari batu bata berdasarkan SNI 152094-2000. Sumber serat lainnya yang dapat dimanfaatkan yaitu tongkol jagung yang merupakan limbah dari jagung yang pemanfaatannya belum optimal. Tanaman jagung merupakan salah satu komoditas pertanian yang produksi nasionalnya cukup tinggi karena jagung merupakan tanaman pangan yang penting di Indonesia. Pada tahun 2018, luas panen jagung Indonesia adalah 3,5 juta hektar dengan produksi rata-rata 3,47 ton/ha. Produksi jagung secara nasional 30 juta ton dan produksi jagung Sumatera Barat pada tahun 2017 adalah 711.532 ton, dengan luas panen 4301 ha dan produktivitas 4,7 ton/ha. Angka ini meningkat dibandingkan tahun 2016 yaitu 474.086 ton dan di Kabupaten Solok produksi jagung tahun 2016 adalah 3.586 ton (BPS Provinsi Sumatera Barat, 2017).

Berdasarkan produksi jagung maka dihasilkan lebih kurang 30\% tongkol jagung. Nilai Residue to Product Ratio (RPR) tongkol jagung adalah 0,273 pada kadar air 7,53\% (Haluti, 2014). Potensi pemanfaatan tongkol jagung diharapkan akan terus meningkat sejalan dengan adanya program peningkatan produksi jagung nasional dari pemerintah. Sumatera Barat sebagai salah satu produsen jagung belum dapat memanfaatkan tongkol jagung dengan optimal. Dengan meningkatnya produksi jagung maka limbah tongkol jagung yang dihasilkan juga bertambah dan akan menjadikan limbah yang berbahaya untuk lingkungan jika tidak ada penanganan yang tepat. Tongkol jagung mngandung 40\% Sellulosa (Haluti, 2014). Dengan komposisi serat tersebut maka tongkol jagung berpeluang dijadikan sebagai bahan substitusi pada pembutan batu bata.

Berdasarkan kondisi tersebut, penulis mencoba memanfaatkan tongkol jagung sebagai bahan substitusi dalam pembuatan batu bata komposit. Tujuan dari penelitian ini adalah menentukan substitusi maksimum pemanfaatan tongkol jagung untuk dapat menghasilkan batu bata dengan kualitas sesuai dengan SNI 15-20942000 (Badan Standarisasi Nasional, 2000). Pemanfaatan tongkol jagung sebagai bahan substitusi tersebut diharapkan dapat mengurangi limbah tongkol jagung dan mengurangi jumlah pemakaian tanah untuk pembuatan batu bata dalam rangka menjaga kualitas lingkungan

\section{Metode}

Lokasi penelitian yaitu di kawasan industri batu bata Nagari Aripan, Kecamatan X Koto Singkarak, Kabupaten Solok. Lokasi ini berada lebih kurang 15 km ke Utara Kota Solok. Bahan yang digunakan adalah tanah lempung sebagai bahan utama pembuatan batu bata, tongkol jagung yang sudah dihaluskan yang berfungsi sebagai bahan substitusi batu bata komposit, air sebagai pelarut tanah lempung (Fernanda, Aldy, Iswan, 2012).

Peralatan penelitian terdiri dari peralatan survey dan peralatan pembuatan batu bata. Peralatan survey yang digunakan yakni Global Positioning System (GPS) dengan merek Garmin, meteran merek Stanley. Peralatan yang digunakan untuk pembuatan batu bata adalah penghalus tongkol jagung, ayakan 60 mesh merek Retsch w. Germany, pengaduk, alat pencetak batu bata berukuran 5,5 cm x 5,5 cm x 5,5 cm, tungku pembakaran untuk pembakar batu bata, satu set alat compression test (uji kuat tekan) merek Wekkob 2153, Neu Wulmshor, oven merek Memmert. 
Pada penelitian yang dilakukan telah dicoba mensubstitusi tanah lempung bahan baku batu bata dengan tongkol jagung yang dihaluskan hingga $>60$ mesh dan $<60$ mesh. Substitusi dilakukan mulai dari $2,5 \%, 5 \%, 7,5 \%, 10 \%$ sampai $12,5 \%$. Variasi bahan batu bata yang dibuat dengan bahan substitusi tongkol jagung berdasarkan pengunaan bahan aditif untuk pembuatan batu bata sesuai Tabel 3, adapun variasi dapat dilihat pada Tabel 1.

Tabel 1

Perhitungan bahan untuk pembuatan batu bata.

\begin{tabular}{lllll}
\hline \multirow{2}{*}{ Perlakuan } & \multicolumn{2}{l}{ Bahan } \\
\cline { 2 - 5 } & \multicolumn{2}{l}{ Tanah Lempung } & \multicolumn{2}{l}{ Tongkol Jagung } \\
\cline { 2 - 5 } & $\%$ & Gram & $\%$ & Gram \\
\hline A & 97,5 & 243,75 & 2,5 & 6,25 \\
B & 95 & 237,5 & 5 & 12,5 \\
C & 92,5 & 231,25 & 7,5 & 18,75 \\
D & 90 & 225 & 10 & 25 \\
E & 87,5 & 218,75 & 12,5 & 31,25 \\
\hline
\end{tabular}

\subsection{Pembuatan batu bata}

Tanah lempung diayak guna memisahkan kerikil ataupun sampah lainnya yang terikut. Tongkol jagung dihaluskan kemudian diayak untuk mendapatkan ukuran $>60$ mesh dan $<60$ mesh. Dilakukan pencampuran tanah lempung, tongkol jagung, dan air 10\% sesuai dengan komposisi yang sudah ditentukan. Tanah lempung yang sudah dicampurkan dengan tongkol jagung dicetak dan diangin-anginkan (tidak terkena matahari langsung) hingga kering. Penjemuran ini dilakukan selama 14 hari sampai batu bata tidak mengandung air. Setelah dijemur, dilakukan pembakaran bahan pada suhu yang dikontrol lebih kurang $600{ }^{\circ} \mathrm{C}$ selama 2 hari. Selanjutnya dilakukan pengujian batu bata untuk daya serap air dan kuat tekan sesuai dengan SNI 15-2094-2000.

\subsection{Pengujian batu bata}

\subsubsection{Pengujian kuat tekan}

Kuat tekan batu bata adalah besarnya beban persatuan luas yang menyebabkan benda uji batu bata hancur bila dibebani dengan gaya tekan tertentu, yang dihasilkan dari alat Universal Testing Machine (UTM). Besarnya kuat tekan dapat dihitung melalui persamaan (1) (Rahman, 2016).

$$
\text { Kuat Tekan }(\mathrm{P})=\frac{F}{A}
$$

$$
\begin{aligned}
& \text { Keterangan : } \\
& \mathrm{F}=\text { Gaya Tekan }(\mathrm{N}) \\
& \mathrm{A}=\text { Luas Penampang }\left(\mathrm{m}^{2}\right)
\end{aligned}
$$

Jika gaya tekan $\mathrm{F}=1 \mathrm{~N}$ bekerja pada luas permukaan $\mathrm{A}$ $=1 \mathrm{~m}^{2}$, maka menurut persamaan (1) kuat tekan adalah:

$$
P=\frac{F}{A}=\frac{1 N}{1 m^{2}}=1^{N} / n^{2}
$$

Dalam satuan internasional (SI), satuan tekanan adalah $\mathrm{N} / \mathrm{m}^{2}$. Satuan tersebut juga diberi nama pascal (disingkat $\mathrm{Pa}$ ). Satuan pascal adalah tekanan yang dilakukan oleh gaya satuan newton pada luas permukaan satu meter persegi.

\subsubsection{Pengujian penyerapan Air}

Batu bata di keringkan dengan menggunakan oven pada suhu $100-110{ }^{\circ} \mathrm{C}$ selama 24 jam. Batu bata ditimbang berat keringnya (a) dan direndam dalam air selama 24 jam, dikeluarkan dan ditimbang (b). Daya serap air dihitung melalui persamaan (3).

$$
\text { Daya serap air }=\{(b-a) / a\} \times 100 \%
$$

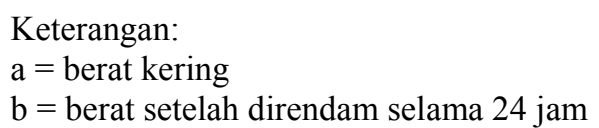

\subsection{Teknik analisis data}

Analisis data dilakukan dengan membuat deskripsi data. Dari deskripsi data dapat dibuatkan tabel nilai kuat tekan dan daya serap air. Kemudian berdasarkan tabel tersebut dibuatkan grafik hubungan ukuran butir tongkol jagung terhadap nilai kuat tekan dan daya serap air. Selanjutnya dilakukan interpretasi dan pembahasan terhadap data dan grafik yang telah dibuat. Interpretasi dan pembahasan terhadap kualitas yang dihasilkan dilakukan dengan membandingkan data yang didapat dari hasil pengujian dengan standar SNI 15-2094-2000.

\subsection{Penurunan laju pemakaian tanah}

Setelah didapatkan komposisi bahan yang optimal agar kualitas batu bata yang dihasilkan memenuhi standar SNI 15-2094-2000, maka dapat dihitung berapa nilai pengurangan laju kerusakan tanah akibat eksploitasi tanah lempung pada industri batu bata di Nagari Aripan, Kabupaten Solok.

\section{Hasil dan pembahasan}

\subsection{Gambaran daerah penelitian}

Lokasi penelitian yaitu di kawasan Industri Batu Bata Aripan yang berjarak $15 \mathrm{~km}$ dari arah Utara Kota Solok. Secara administrasi lokasi industri ini berada di Nagari Aripan, Kecamatan X Koto Singkarak, Kabupaten Solok. Di sekitar kawasan industri batu bata Aripan terdapat hutan reboisasi pinus dan juga sawah masyarakat. Kegiatan usaha industri batu bata berawal pada tahun 1987 dan berkembang pesat sejak tahun 1990. Kawasan industri batu bata Nagari Aripan bukan area yang diperuntukkan untuk kegiatan pertanian karena jenis tanahnya yang tidak subur. Sejak awal mulainya kegiatan industri batu bata pada tahun 1987 hingga sekarang, jumlah bedeng batu bata di Nagari Aripan ini yaitu lebih kurang 900 bedeng. Saat ini jumlah bedeng yang beroperasi lebih kurang 500 bedeng (RPJM Nagari Aripan 2011-2016).

Nagari Aripan sebagai daerah penghasil batu bata di Provinsi Sumatera Barat didukung oleh kualitas 
tanahnya yang cocok untuk pembuatan batu bata. Untuk dapat mendukung permintaan pasar terhadap batu bata daerah ini, maka proses eksploitasi tanah lempung terus dilakukan. Proses penggalian tanah lempung dilakukan sehingga melampaui kemampuan tanah untuk membentuk struktur tanah kembali adapun luas area terbuka di beberapa titik lokasi kegiatan penambangan tanah lempung di Nagari Aripan Kecamatan X Koto Singkarak, Kabupaten Solok dapat dilihat pada Tabel 2.

Tabel 2

Luas area terbuka di beberapa titik lokasi kegiatan penambangan tanah lempung di Nagari Aripan Kecamatan X Koto Singkarak, Kabupaten Solok

\begin{tabular}{lllll} 
No & Lokasi & Luas $\left(\mathrm{m}^{2}\right)$ & Tinggi $(\mathrm{m})$ & Volume $\left(\mathrm{m}^{3}\right)$ \\
\hline 1. & I & 85,55 & 3 & 256,65 \\
2. & II & 1212,08 & 4 & 4848,32 \\
3. & III & 247,43 & 8 & 1979,44 \\
4. & IV & 229,15 & 4 & 916,60 \\
5. & V & 135,79 & 3 & 407,37 \\
6. & VI & 987,29 & 4 & 3949,16 \\
7. & VII & 470,65 & 5 & 2353,25
\end{tabular}

Sumber: Hasil pengukuran pada lokasi penelitian dengan menentukan titik koordinat lokasi menggunakan GPS

Berdasarkan Keputusan Menteri Lingkungan Hidup Nomor 43 Tahun 1996 tentang Kriteria Kerusakan Lingkungan Bagi Usaha atau Kegiatan Penambangan Bahan Galian Golongan C Jenis Lepas di Daratan maka lahan penambangan batu bata di Nagari Aripan ini telah tergolong rusak. Lampiran 1 Keputusan Menteri Negara
Lingkungan Hidup Nomor 43 menyatakan bahwa kedalaman lubang untuk daerah pemukiman dan daerah industri lebih dalam 1 meter di atas muka air tanah pada musim hujan dinyatakan rusak. Berdasarkan Lampiran 2 Keputusan Menteri Negara Lingkungan Hidup Nomor 43 dinyatakan bahwa kedalaman lubang galian adalah jarak vertikal dari permukaan lahan hingga ke dasar lubang galian. Masalah ini menjadi kewajiban untuk mencarikan solusi pengelolaan lingkungan hidup yang bertolak kepada pilar pembangunan berkelanjutan. Seperti dinyatakan dalam Undang-undang Nomor 32 Tahun 2009 tentang Perlindungan dan Pengelolaan Lingkungan Hidup, Pasal 67 menyatakan, "Setiap orang berkewajiban memelihara kelestarian lingkungan hidup serta mengendalikan pencemaran dan/atau kerusakan lingkungan hidup".

Kerusakan lingkungan akibat penambangan tanah lempung pada industri batu bata menjadi dampak yang perlu dicarikan solusinya. Pengendalian terhadap kerusakan tanah ini salah satunya dapat dilakukan dengan cara mencarikan bahan pengganti tanah untuk pembuatan batu bata. Penggantian ataupun substitusi tanah yaitu dengan menambahkan bahan lain sebagai bahan baku pembuatan batu bata. Penambahan bahan lain tersebut dapat berupa serat ataupun bahan-bahan lain yang memiliki fungsi yang sama atau bahkan meningkatkan kualitas batu bata. Beberapa bahan yang dapat dimanfaatkan sebagai bahan substitusi tanah dalam pembuatan batu bata telah dilakukan oleh (Chan, 2011; Hamdi, 2008; Liemawan, 2012) dapat dilihat pada Tabel 3.

Tabel 3

Beberapa serat yang dapat dimanfaatkan sebagai bahan substitusi pembuatan batu bata.

\begin{tabular}{lllll}
\hline No. & Nama Peneliti & Tahun & Jenis Bahan Substitusi & Jumlah Pemanfaatan (\%) \\
\hline 1. & Hamdi & 2008 & Sekam gergaji & 10 \\
2. & Chan & 2011 & Serat nenas dan serat kelapa sawit & 0,75 \\
3. & Liemawan & 2012 & Ampas tebu & 12 \\
\hline
\end{tabular}

Tabel 4

Data analisis kuat tekan dan daya serap air batu bata dengan bahan substitusi tongkol jagung

\begin{tabular}{llllll}
\multirow{2}{*}{ No. Jumlah Tongkol Jagung $(\%)$} & \multicolumn{2}{l}{ Kuat Tekan $\left(\mathrm{kgf} / \mathrm{cm}^{2}\right)$} & \multicolumn{2}{l}{ Daya Serap (\%) } \\
\cline { 3 - 6 } & & $\leq 60$ mesh & 760 mesh & $<60$ mesh & $>60$ mesh \\
\hline 1. & 0 & 79,96 & 79,96 & 25,67 & 25,67 \\
2. & 2,5 & 60,62 & 79,38 & 26,62 & 26.58 \\
3. & 5 & 55,56 & 55,66 & 29,89 & 30,28 \\
4. & 7,5 & 50,30 & 55,48 & 30,40 & 32,22 \\
5. & 10 & 44,48 & 50,68 & 29,76 & 32,49 \\
6. & 12,5 & 41,54 & 50,28 & 34,76 & 33,51 \\
\hline
\end{tabular}

\subsection{Kuat tekan batu bata}

Hasil pengujian kuat tekan batu bata yang dibuat dengan bahan substitusi tongkol jagung dapat dilihat pada Tabel 4. Dari data tersebut didapatkan grafik pengaruh jumlah tongkol jagung terhadap kuat tekan batu bata.

Gambar 1 menunjukan bahwa substitusi tongkol jagung dengan ukuran butir $<60$ mesh dengan penambahan tongkol jagung $0 \%, 2,5 \%, 5 \%$ dan $7,5 \%$, hasil kuat tekan didapat berturut-turut sebesar 79,96 $\mathrm{kg} / \mathrm{cm}^{2}, 60,62 \mathrm{~kg} / \mathrm{cm}^{2}, 55,56 \mathrm{~kg} / \mathrm{cm}^{2}$ dan $50,30 \mathrm{~kg} / \mathrm{cm}^{2}$. Kuat tekan sampai substitusi $7,5 \%$ yang menghasilkan batu bata kelas 50 standar SNI 15-2094-2000 dimana kuat tekan minimal $50 \mathrm{~kg} / \mathrm{cm}^{2}$. Apabila substitusi serat tongkol jagung dinaikan $10 \%$ dan $12,5 \%$ menunjukan nilai kuat tekan batu bata tidak memenuhi standar kualitas batu bata.

Semakin besar persen penambahan tongkol jagung semakin kecil kuat tekan. Menurut (Prayuda et al., 2018) hubungan kuat tekan dengan kerapatan, bahwa semakin besar kerapatan maka semakin besar nilai kuat tekan, 
jadi untuk meningkatkan kuat tekan pada batu bata diperlukan kerapatan batu bata. Kuat tekan batu bata dengan kehalusan tongkol jagung $<60$ mesh, semakin tinggi persentase tongkol jagung yang digunakan, semakin rendah kerapatan batu bata dan terbentuknya rongga-rongga yang menyebabkan semakin kecil hasil kuat tekan. Sebaliknya semakin kecil penambahan tongkol jagung, semakin tinggi kerapatan dan ronggarongga yang terbentuk semakin kecil sehingga kuat tekan yang dihasilkan semakin besar.

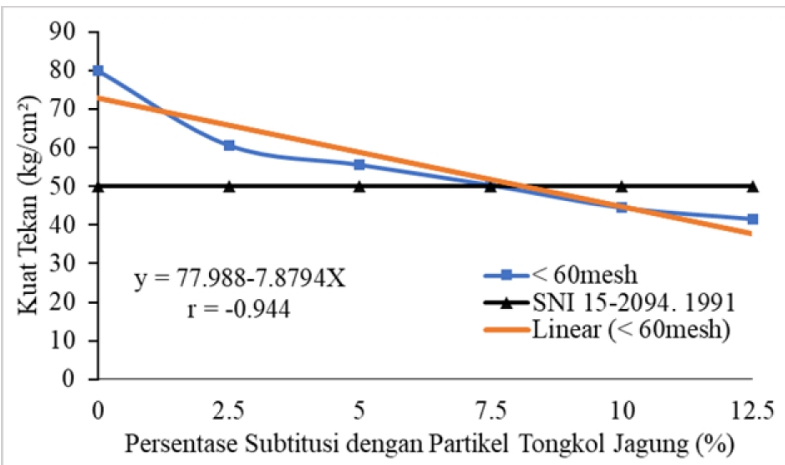

Gambar 1. Grafik hubungan \% tongkol jagung $<60$ mesh terhadap kuat tekan batu bata

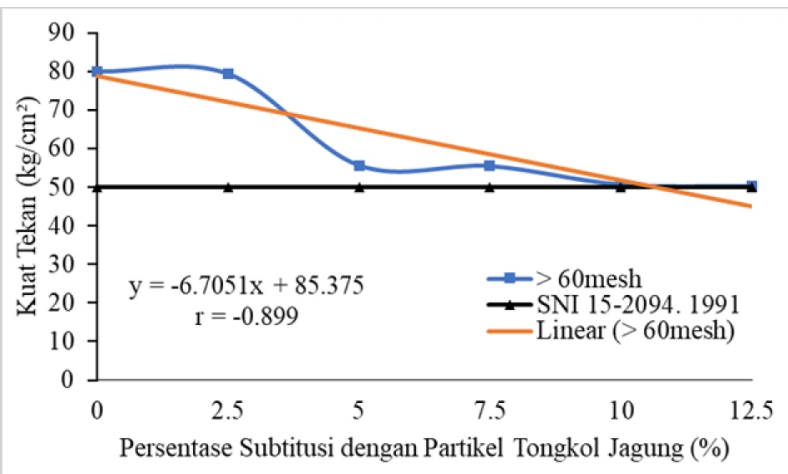

Gambar 2. Grafik hubungan \% tongkol jagung $>60$ mesh terhadap kuat tekan batu bata

Hasil analisis kuat tekan batu bata pada penambahan tongkol jagung dengan ukuran butir $>60$ mesh dan varaisi penambahan $0 \%, 2,5 \%, 5 \%, 7,5 \%, 10 \%$ dan $12,5 \%$ dapat dilihat pada Gambar 2. Kuat tekan batu bata masing-masing 79,96 kg/cm², 79,38 kg/ $\mathrm{cm}^{2}, \quad 55,66$ $\mathrm{kg} / \mathrm{cm}^{2}, 50,48 \mathrm{~kg} / \mathrm{cm}^{2}, 50,68 \mathrm{~kg} / \mathrm{cm}^{2}$ dan $50,28 \mathrm{~kg} / \mathrm{cm}^{2}$. Hasil kuat tekan sampai dengan penambahan 12,5\% memenuhi kelas 50 standar SNI 15-2094-2000 (Badan Standarisasi Nasional, 2000). Hal ini menunjukkan bahwa penambahan serat tongkol jagung dengan ukuran butir kehalusan $>60$ mesh hingga $12,5 \%$ masih memenuhi mutu batu bata bila dibandingkan kelas 50 sesuai dengan SNI 15-2094-2000.

Berdasarkan Gambar 1 dan Gambar 2 dapat diketahui bahwa substitusi partikel tongkol jagung pada pembuatan batu bata komposit berpengaruh terhadap kuat tekan. Ini berarti kekuatan batu bata komposit akan semakin berkurang dengan semakin ditingkatkannya jumlah substitusi tongkol jagung. Terjadinya penurunan kuat tekan sesuai dengan penelitian (Rahmawati and Nugroho Saputro, 2015) bahwa dengan penambahan bahan aditif pada pembuatan batu bata diatas 10\% mengalami penurunan kekuatan batu bata. Hal tersebut terjadi karena adanya gaya ikat antara partikel tanah dan bahan aditif memiliki daya ikat yang lemah.

\subsection{Daya serap air}

Sifat batu bata yang penting juga adalah daya serap air. Hasil uji daya serap air pada batu bata yang disubstitusi tanah dengan partikel tongkol jagung ditampilkan pada Tabel 4. Dari data tersebut didapatkan grafik pengaruh jumlah tongkol jagung terhadap daya serap air batu bata.

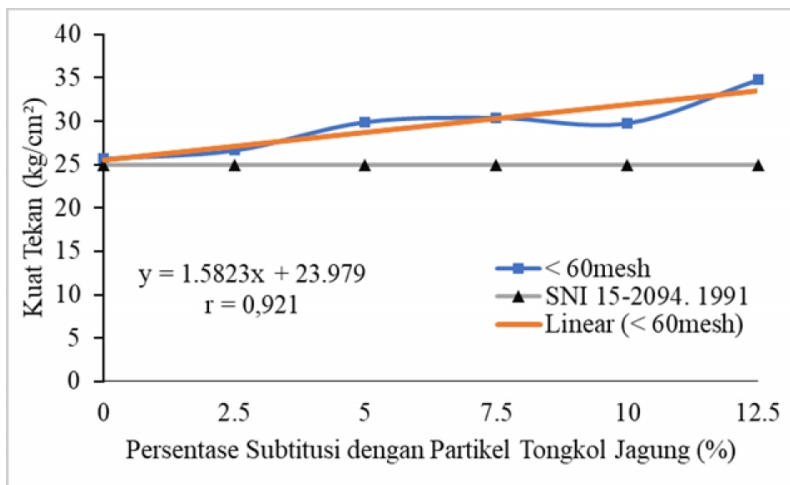

Gambar 3. Grafik hubungan \% tongkol jagung $>60$ mesh terhadap daya serap air batu bata

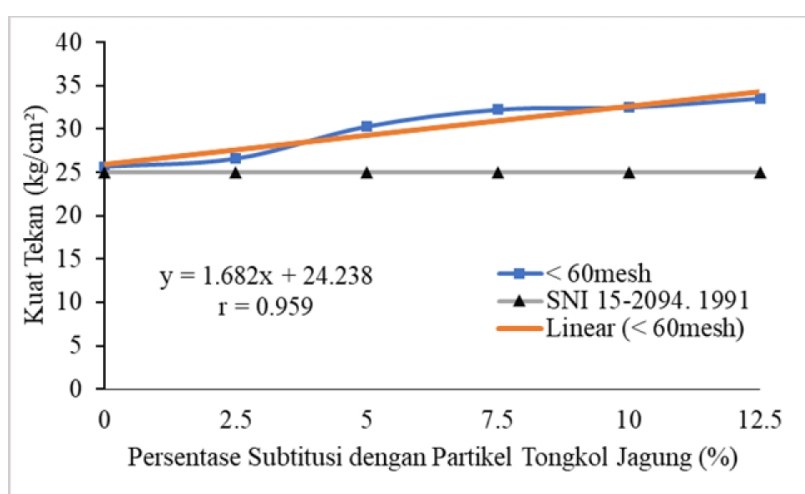

Gambar 4. Grafik hubungan \% tongkol jagung $<60$ mesh terhadap daya serap air batu bata

Gambar 3 menunjukkan daya serap air batu bata komposit untuk substitusi tongkol jagung dengan ukuran butir $>60$ mesh melebihi standar mutu yang ditetapkan SNI 15-2094-2000. Hal ini disebabkan karena sifat dari serat yang menyerap air

Gambar 4 menunjukkan nilai daya serap air batu bata yang juga melebihi SNI 15-2094-2000 untuk setiap persentase penambahan tongkol jagung. Jadi dapat diketahui bahwa penambahan serat tongkol jagung pada pembuatan batu bata meningkatkan daya serap air pada batu bata. Daya serap air yang diperoleh lebih dari $20 \%$. Sementara daya serap air maksimal yang diperbolehkan berdasarkan SNI 15-2094-2000 adalah 20\%.

Daya serap air harus dikontrol untuk mencegah kehilangan air dari adukan yang digunakan. Dari Gambar 3 dan Gambar 4 dapat diketahui bahwa substitusi partikel tongkol jagung pada pembuatan batu bata komposit akan berpengaruh positif terhadap daya 
serap air. Hal ini berarti dengan ditingkatkannya jumlah penambahan partikel tongkol jagung pada pembuatan batu bata komposit, maka daya serap batu bata komposit terhadap air akan semakin meningkat. Hal ini diperkirakan karena tanah lempung mempunyai berat jenis yang lebih besar dibandingkan dengan tongkol jagung. Semakin tinggi berat jenis semakin baik konduktivitas termalnya. Konduktivitas termal adalah suatu besaran intensif bahan yang menunjukkan kemampuannya untuk menghantarkan panas. Faktorfaktor yang mempengaruhi konduktivitas termal diantaranya adalah suhu, kandungan uap air, berat jenis dan keadaan pori-pori bahan. Saat batu-bata bersumber bahan baku tanah lempung dipanaskan, batu-bata tersebut mampu menghantarkan dan melepaskan panas yang diterimanya dengan baik ke lingkungan (Mulyati et al., 2017).

Tongkol jagung mempunyai struktur yang berongga besar dibandingkan dengan tanah lempung, berat jenis yang lebih ringan dibandingkan dengan tanah lempung, sehingga tongkol jagung bukanlah sebagai konduktor yang baik, melainkan sebagai isolator yang baik. Kemampuan material tongkol jagung menahan panas lebih lama saat dipanaskan, disamping itu dengan strukturnya yang berongga, menjadikan batu-bata berbahan tambahan tongkol jagung lebih ringan dan lebih banyak menyerap air dibandingkan dengan tanah lempung.

Untuk itu, pada pengerjaan tembok/dinding dengan daya serap air pada bata yang tidak sebanding dapat menimbulkan deferensial serta retak-retak. Untuk menyamakan daya serap air, batu bata yang mempunyai daya serap air tinggi perlu dilakukan perendaman dalam air sampai tidak ada gelembung air sebelum dilakukan pemasangan (Amran and Rinaldi, 2016). Perendaman tersebut dimaksudkan agar tidak menurunkan kualitas struktural yang dihasilkan.

\subsection{Penurunan laju pemakaian tanah dengan adanya substitusi partikel tongkol jagung}

Berdasarkan hasil pengujian terhadap kualitas kuat tekan batu bata komposit tongkol jagung, maka dapat diketahui kualitas batu bata masih memenuhi standar SNI 15-2094-2000 untuk mutu bata kualitas 50 . Penambahan maksimal hingga $12,5 \%$ serat masih dapat dilakukan untuk ukuran butir tongkol jagung $>60$ mesh.

Berdasarkan survey, kebutuhan tanah lempung per tahunnya untuk bahan baku batu bata adalah $26.090 \mathrm{~m}^{3}$. Berdasarkan penelitian yang telah dilakukan, diketahui bahwa tanah dapat disubstitusi dengan tongkol jagung hingga $12,5 \%$ dengan ukuran butir tongkol jagung $>60$ mesh. Jadi, dengan kebutuhan bahan baku $26.090 \mathrm{~m}^{3}$ per tahunnya atau $70.704 \mathrm{~kg}$ per tahunnya, dibutuhkan 8.838 $\mathrm{kg}$ tongkol jagung.

Penurunan jumlah pemakaian tanah jika tanah lempung sebagai bahan utama pembuatan batu bata digantikan dengan serat tongkol jagung sebanyak 12,5\% ditampilkan pada Tabel 5. Perbandingan penurunan laju pemakaian tanah antara batu bata dengan substitusi tongkol jagung dengan batu bata tanpa substitusi dapat dilihat pada Gambar 5.

Tabel 5

Pengurangan pemakaian tanah dengan substitusi tongkol jagung

\begin{tabular}{llllll}
\hline No & Lokasi & $\begin{array}{l}\text { Volume } \\
\left(\mathrm{m}^{3}\right)\end{array}$ & $\begin{array}{l}\text { Massa } \\
(\mathrm{kg})\end{array}$ & $\begin{array}{l}\text { Massa tanah yang dibutuhkan } \\
\text { jika disubstitusi }(\mathrm{kg})\end{array}$ & $\begin{array}{l}\text { Jumlah pengurangan } \\
(\mathrm{kg})\end{array}$ \\
\hline 1. & I & 256,65 & 695,52 & 608,58 & 86,94 \\
2. & II & 4848,32 & $13.138,95$ & $11.496,58$ & 1642,37 \\
3. & III & 1484,58 & $4.023,21$ & $3.520,31$ & 502,90 \\
4. & IV & 916,60 & $2.489,41$ & $2.178,23$ & 311,18 \\
5. & V & 407,37 & $1.103,97$ & 965.97 & 138,00 \\
6. & VI & 3949,16 & $10.702,22$ & $9.364,44$ & 1337,78 \\
7. & VII & 2353,25 & $6.377,31$ & $5.580,15$ & 797,16 \\
\hline
\end{tabular}

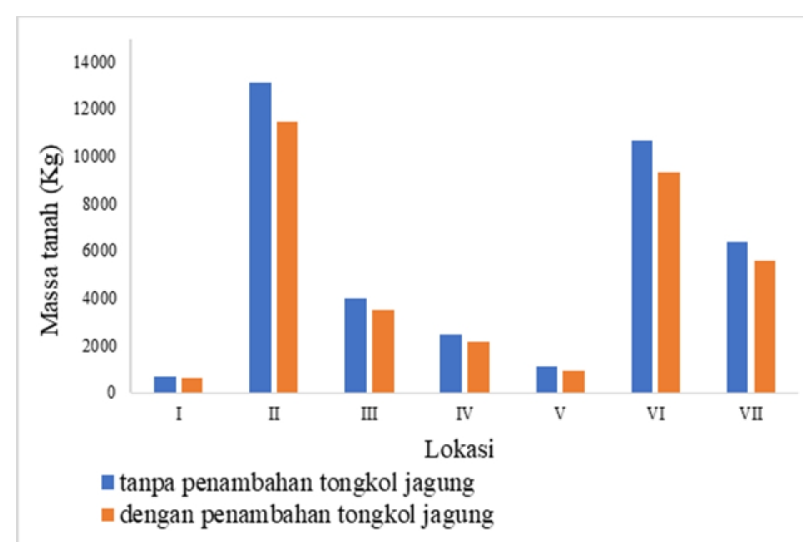

Gambar 5. Grafik penurunan pemakaian tanah dengan penambahan tongkol jagung untuk pembuatan batu bata

Berdasarkan data produksi jagung di Kabupaten Solok sebanyak 3.586 ton/tahun akan dapat memenuhi kebutuhan pembuatan batu bata komposit, dengan asumsi 30\% tongkol jagung dapat dimanfaatkan sebagai bahan substitusi pembuatan batu bata. Pada pembuatan batu bata komposit tongkol jagung, bahan tongkol jagung berfungsi sebagai pengikat. Diduga tongkol jagung yang disubstitusikan pada tanah lempung yang dibakar pada temperatur tinggi yaitu hingga $600{ }^{\circ} \mathrm{C}$ akan menghasilkan abu tongkol jagung yang mengandung silika dan alumina. Senyawa silika dan alumina ini merupakan senyawa dominan di dalam tanah lempung (Raheem and Adesanya, 2011). Dengan adanya kandungan silika dan alumina tersebut, maka pada proses pembakaran senyawa yang terkandung dalam tanah lempung dan abu tongkol jagung akan saling berikatan membentuk $3 \mathrm{Al}_{2} \mathrm{O}_{3} \cdot 2 \mathrm{SiO}_{2}$ (Al-Amaireh, 2009). Reaksi silika dan alumina pada proses pembakaran batu bata dapat dilihat pada persamaan (4). 


$$
\mathrm{Al}_{2} \mathrm{O}_{3}+\mathrm{SiO}_{2} \underset{\mathrm{O}_{2}}{\nearrow} 3 \mathrm{Al}_{2} \mathrm{O}_{3} \cdot 2 \mathrm{SiO}_{2}
$$

\section{Kesimpulan}

Dari hasil penelitian diperoleh hasil uji kuat tekan perlakuan kehalusan tongkol jagung $>60$ mesh dengan penambahan hingga 12,5\% masih memenuhi baku mutu batu bata kualitas kuat tekan $50 \mathrm{~kg} / \mathrm{cm}^{2}$ (kelas 50) berdasarkan SNI 15-2094-2000. Penambahan ukuran butir tongkol jagung $<60$ mesh sampai perlakuan 7,5\% yang memenuhi kualitas kuat tekan, sedangkan penambahan tongkol jagung $10 \%$ dan $12,5 \%$ tidak memenuhi baku mutu kuat tekan sesuai SNI 15-20942000 (kelas 50). Uji daya serap air batu bata komposit dengan substitusi tongkol jagung diperoleh, semakin besar penambahan tongkol jagung baik perlakuan $<60$ mesh dan perlakuan $>60$ mesh, daya serap air rata-rata didapat diatas $20 \%$. Hal ini belum memenuhi standard kualitas daya serap air berdasarkan SNI 15-2094-2000.

Berdasarkan potensi material tongkol jagung di Kabupaten Solok sebanyak 3.586 ton per tahun dihasilkan tongkol jagung 30\%. Kebutuhan tanah untuk produksi batu bata saat ini $26.090 \mathrm{~m}^{3}$ per tahun dan membutuhkan substitusi serat tongkol jagung sebanyak $8.838 \mathrm{~kg}$. hal ini akan mencukupi apabila digunakan sebagai bahan substitusi pada pembuatan batu bata komposit dan akhirnya bisa menurunkan jumlah pemakaian tanah lempung sebagai bahan utama pembuatan batu bata di Nagari Aripan.

\section{Daftar pustaka}

Al-Amaireh, M.N., 2009. Production of fire-clay refractory bricks from local materials. Eur. J. Sci. Res. 26, 386-392.

Amran, Y., Rinaldi, R., 2016. Pemanfaatan abu ampas tebu sebagai bahan campuran untuk memperbaiki sifat fisik dan mekanisme bata. Tapak 6 no 1, 64-70.

Badan Standarisasi Nasional, 2000. SNI 15-2094-2000: Bata merah pejal untuk pasangan dinding. Badan Standarisasi Nas.

BPS Provinsi Sumatera Barat, 2017. Sumatera Barat dalam Angka Tahun 2017. Padang.

Chan, C.M., 2011. Effect of natural fibres inclusion in clay bricks: Physico-mechanical properties. World Acad. Sci. Eng. Technol. 73, 51-57.

Fattah, A., Nabi, A., 2018. Pemanfaatan limbah ampas tebu pada pembautan batu bata 2018, 208-214.

Fernanda, Aldy, Iswan, S., 2012. Studi kekuatan pasangan Batu Bata pasca pembakaran menggunakan Bahan Additive Zeolit. Univ. Negri lampung 1, 371381.

Firmansyah, M.A., Sudarsono, Pawitan, H., Djuniwati, S., Djajakirana, G., 2008. Karakterisasi dan resiliensi tanah terdegradasi di lahan kering Kalimantan Tengah. J. Tanah dan Iklim 27, 21-32.

Haluti, S., 2014. Pemetaan potensi limbah tongkol jagung. Institut Teknologi Sepuluh Nopember.

Hamdi, khairul, 2008. Fisis batu bata komposit dengan optimasi ukuran butir terhadap sifat bahan penguat serat kayu penggergajian. Universitas negeri Padang.

Handayani, S., 2010. Kualitas batu bata merah dengan penambahan serbuk gergaji. Tek. Sipil Perenc. 12, 41-50. https://doi.org/10.15294/jtsp.v12i1.1339

Kepmen Lingkungan Hidup, 1996. Kepmen Lingkungan Hidup N0 43 tahun 1996.

Liemawan, A.E., 2012. Rekayasa batu bata ringan dengan tambahan campuran ampas tebu dan pengujiannya. Universitas Brawijaya.

Mulyati, S.S., Pujiono, P., Prijanto, T.B., Fikri, E., 2017. Analisis kualitas batu-bata bersumber bahan tambahan sampah serbuk gergaji dalam berbagai variasi berat. J. Kesehat. Lingkung. Indones. 16, 46. https://doi.org/10.14710/jkli.16.2.46-50

Prayuda, H., Setyawan, E.A., Saleh, F., 2018. Analisis sifat fisik dan mekanik batu bata merah Yogyakarta (Analysis Physical and mechanical attributes of masonry in Yogyakarta). J. Ris. Rekayasa Sipil 1, 94. https://doi.org/10.20961/jrrs.v1i2.20658

Raheem, A.A., Adesanya, P.D.A., 2011. A study of thermal conductivity of corn cob ash blended cement mortar. Pacific J. Sci. Technol. 12, 106-111.

Rahman, H.A., 2016. Uji kuat tekan bata merah mengunakan mortar pasir kwarsa. Universitas Brawijaya Malang.

Rahmawati, A., Nugroho Saputro, I., 2015. Penambahan abu jerami dan abu sekam padi pada campuran batu bata untuk meningkatkan kualitas dan efisiensi produksi batu bata industri tradisional. Staf pengajar Progr. Stud. Pendidik. Tek. Bangunan 11, 16. 